IJBE (Integrated Journal of Business and Economics)

e-ISSN: 2549-3280/p-ISSN: 2549-5933

\title{
The Importance of Education in Peace Marketing
}

\author{
Margarita Išoraitė \\ Vilniaus Kolegija / University of Applied Sciences \\ misoraite@gmail.com
}

\begin{abstract}
Peace defined means the absence of war. War and peace have always been not only military but also political issues advantage. Educational systems are confronted with exceptional challenges during violent conflict. During the conflict International humanitarian law is particularly important. Geneva Conventions a specific reference to protection related to education in wartime. Education peace is also related to the creation of values and skills that help students achieve fullness a life that embraces all people. Education peace relates to aid pupils to recognize many forms and causes violence and promote values and skills to live society. Peace marketing is trying to influence social behavior, change attitudes, habits, and not to the marketing person, but to the benefits of society in general. Article analyzes peace education concepts, role education in promoting peace marketing, universities peace initiative.
\end{abstract}

\section{Article Info}

- Received : August 21, 2018

- Revised : November 3, 2018

- Published : January 5, 2019

- No. Pages : 43-51

- DOI : 10.33019/ijbe.v3i1.101

- JEL : I21, M31

- Keywords : peace, peace education, peace education, peace initiative

\section{Introduction}

Peace has a profound effect on education. Peace can help achieve the right to basic quality education. Peace education helps young people gain knowledge, enhance their skills in the area of peace, and form an attitude about the meaning of peace in human life. Peace education prevents the emergence of conflicts and creates conditions for peace in the world. That is why peace education is very important in the world. Peace education activities promote conflict resolution that promotes peace and values such as respect for human rights, freedom and confidence. Peacemaking is not part of the modern world. Today's educational institutions are against violence. Although there are educational institutions in the world that are violent. But a society without education is not progressive. Article will analyze peace education concept, the importance of education in peace marketing, education institutions active with peace.

United Nations stated that every year on September 21 worldwide observance of International Peace Day. The General Assembly announced that it is a day dedicated to strengthening the ideals of peace in all peoples and among nations. Page, J. (2008) stated that "peace education is now well recognized within international legal instruments and within critical educational 
literature as an important aspect of education. This study examines a number of possible ethical and philosophical foundations for the development of peace, examining five specific ethical traditions: 1) ethics of virtue, 2) consecutive ethics, 3) conservative political ethics, 4) aesthetic ethics, 5) care ethics, where care can be understood as a key element of peace and peace education as it promotes confidence and cooperation with others."

Peace education aims to help students; students acquire the skills needed to solve unwise conflict resolution problems and strengthen these skills for active and responsible action by the public to promote peace values. Consequently, unlike the concept of a conflict resolution that can be considered retroactive, peace education is more focused on resolving the conflict after it has already taken place. Its purpose is to prevent a conflict in advance or to promote the development of people and society in a peaceful way, based on the principles of harm, tolerance, equality, respect for social justice and social justice. Subject education helps students to stay calm and not conflict with educational institutions.

\section{Table 1. Definition Peace Education}

\begin{tabular}{|c|l|}
\hline Author & \multicolumn{1}{|c|}{ Definition } \\
\hline Gutek, G. L. (2006). & $\begin{array}{l}\text { Peace education can be analyzed as the attempt to provide values } \\
\text { education and social skills that would reinforce positive group } \\
\text { interactions among vastly different cultures and countries. }\end{array}$ \\
\hline Ajala, E.M. (2003) & $\begin{array}{l}\text { Peace education of the nation as the type of education that influences } \\
\text { learners with all the norms, values and attitudes that can create a } \\
\text { supportive environment in human life. }\end{array}$ \\
\hline Mahmood, A., Ashraf, I. & $\begin{array}{l}\text { Peace education often referred to as conflict resolution education, has its } \\
\text { origins in the ideas of Comenius and Erasmus. Peace education is a } \\
\text { unifying and comprehensive concept that seeks to promote a holistic } \\
\text { view of education. However, its relevance is inextricably part of and is } \\
\text { highly dependent on contextual specificity. }\end{array}$ \\
\hline Lirola, M., M. (2016) & $\begin{array}{l}\text { Peace education (PE) is a pedagogical proposal that can contribute to } \\
\text { improving not only the teaching-learning process but also the world. }\end{array}$ \\
\hline Lirola, M., M. (2007) & $\begin{array}{l}\text { PE is also a proposal to deconstruct power in the classroom. A classroom } \\
\text { framed in the principles of PE highlights that teachers and students share } \\
\text { the responsibility in the teaching-learning process so that the traditional } \\
\text { role of teachers as authority and source of knowledge is substituted by } \\
\text { that of facilitator, guide, coach, and tutor, among others }\end{array}$ \\
\hline Ran, I. (2015) & $\begin{array}{l}\text { In tracing the recent development of peace education, we begin to see } \\
\text { that in the past it had been an integral part of education at all times and in } \\
\text { all Role of Education in Inculcation of Education For Peace 107 cultures, } \\
\text { Every culture regards peace as a noble ideal to attain. However with the } \\
\text { advent of Western secularism at the beginning of the 20th century } \\
\text { through the guise of a positivist scientific outlook to education, moral and } \\
\text { human values including peace was slowly discouraged away from school } \\
\text { curricula. }\end{array}$ \\
\hline
\end{tabular}

\section{Role Education in Promoting Peace Marketing}

The problems of global war are increasingly affecting the lives of every human being, which is why everyone needs it to realize that we are in a world in which poverty, social inequality and 
climate are still flourishing the problem of change and global warming. In today's society, it is extremely important that education in various forms would encourage people to understand these challenges better. and their impact on the personal, community, country.

Peace education for peace is the key to building a peaceful culture. The United Nations has called on each country "to ensure that children from the very early age receive educational benefits so that they can resolve any dispute peacefully and with respect for human dignity and tolerance."

Dulnuan, W. (2015) analyzed peace education importance stated that ,the following are reasons peace education must be taught in schools:

1. To provide students with the capability and values they must have to build and sustain peace in their respective families, friends, community, workplace, country, world, and within themselves.

2. To constructively handle the after-effects of war or conflict and the presence of violence in individuals' daily lives like increased violence and aggression.

3. To develop social responsibility which is needed in the 21 st century.

4. To provide hope for a better future for the younger members of society, because it indicates that their society is aware of its ills and its ills and is striving o remedy them in order to build a better place to live.

United Nations Children's Fund (2011) mentioned that the first area related to "education in emergency situations" and gives priority to the protection of the child and responding to the negative impact of the conflict on their education, both deal with access, but also in the case of psychosocial support in the event of trauma. That's it programs are usually organized in the context of humanitarian aid. The second area the literature emphasizes the need for "conflictrelated" education that "does not harm" because for example, ensuring that education does not increase inequality or the division of fuels, such as inappropriate teaching language or teaching content. It can also include peace education, formally through the curriculum and through the non-formal education program delivery mechanisms."

Table 2. Role Education for Promotion Peace Marketing

\begin{tabular}{|c|l|}
\hline Author & \multicolumn{1}{|c|}{ Definition } \\
\hline & $\begin{array}{l}\text { "Educating for peace does not imply guaranteeing idealistic living } \\
\text { conditions a priori. Rather, it encourages acceptance of the idea of peaceful } \\
\text { coexistence, awareness of it as a positive possibility, and investment in } \\
\text { tools and actions which will promote its evolution. Positive peace requires } \\
\text { planning, intervention, and participation. Additionally, there are important } \\
\text { societal conditions, relationships, and states of mind resting on shared } \\
\text { values of harmony, justice, equity, and safeguarding wealth and quality of } \\
\text { life. The educational projects must be open to all, necessitating a } \\
\text { commitment to deconstructing all forms of marginalization, racism, anti- } \\
\text { Semitism and xenophobia“. }\end{array}$ \\
\hline \multirow{3}{*}{ McGuire, D. (2016) } & $\begin{array}{l}\text { Peace education is crucial for building a culture that reduces the need for } \\
\text { peacekeeping and peacekeeping by creating a comprehensive program that } \\
\text { teaches people to interact with others and avoid unnecessary aggression. }\end{array}$ \\
\hline
\end{tabular}


IJBE (Integrated Journal of Business and Economics)

e-ISSN: 2549-3280/p-ISSN: 2549-5933

\begin{tabular}{|c|c|}
\hline Author & Definition \\
\hline & $\begin{array}{l}\text { There are ten major peace-building goals or peace-building. These goals } \\
\text { are based on the assumption that, although violent conflict is inevitable, it } \\
\text { is a process by which we can resolve conflicts and reduce violence. Peace } \\
\text { education aims to reduce violence and promote peace-building in order to } \\
\text { inform the instructions }\end{array}$ \\
\hline Dupuy, K. (2008) & $\begin{array}{l}\text { Formal education systems could play an important role an outbreak of } \\
\text { armed conflict, such as failure to provide appropriate educational } \\
\text { opportunities or posting stereotypes and the military ideology curriculum. } \\
\text { By the way, the issue of education is closely linked to the root causes of } \\
\text { conflicts, such as resource allocation, access to political power society and } \\
\text { the recognition of identity and cultural development (Degu, 2005). }\end{array}$ \\
\hline $\begin{array}{c}\text { Spruyt,B., Elchardus, } \\
\text { M., Roggemans, L., Van } \\
\text { Droogenbroeck, F. } \\
\text { (2014) }\end{array}$ & $\begin{array}{l}\text { There are several reasons why education is a major focus on how to } \\
\text { contribute to a peaceful culture. In the first place, there have traditionally } \\
\text { been high expectations of socialization and unifying potential school } \\
\text { education in regions where there are serious conflicts and war. Explicit } \\
\text { references to education are not customary in peace agreements. In regions } \\
\text { where such conflicts do not exist or occur. To a lesser extent, the } \\
\text { expansion of the educational method can be observed. Education is not } \\
\text { limited to expected to prepare young people for the labor market, but also } \\
\text { to provide the basis for casting them to good citizens. This means that } \\
\text { attention will be paid to specific business knowledge and skills. }\end{array}$ \\
\hline Kester, K. (2009) & $\begin{array}{l}\text { Peace education includes the development of peacebuilding skills (e.g. } \\
\text { dialogue, mediation, artistic exercise). Then, teachers teach the values of } \\
\text { respect, understanding and non-distortion, provide skills for analyzing } \\
\text { international conflicts, develop alternative security systems and use } \\
\text { democratic and participatory pedagogy. Therefore, peace education as } \\
\text { practice and philosophy means the harmonized elements of education and } \\
\text { society that contain social goals ( why to teach), the content (what to } \\
\text { teach) and pedagogy ( how to teach) about the educational process. } \\
\text { promotes peace. Therefore, peacebuilding is a collaborative learning } \\
\text { experience, where learners deal with contemporary problems language } \\
\text { points), which are related to local and global contexts jointly and } \\
\text { collectively. }\end{array}$ \\
\hline Novakova, P. (2010) & $\begin{array}{l}\text { Education can have a constructive and harmful effect, and many of the } \\
\text { current conflicts are called ethnic conflicts. As indicated by ethnic } \\
\text { conflicts some are motivated by their religion, traditions, skin color, or any } \\
\text { other another reason that is not openly ideological or economic "(Bush \& } \\
\text { Salterelli, 2000, p. 7). These motives are social constructs, so the statement } \\
\text { that education can be harmful either a constructive role in the reproduction } \\
\text { of society is emphasized, and it can be argued that education is an } \\
\text { important role in the peace process }\end{array}$ \\
\hline $\begin{array}{c}\text { El-Bushra, J., Smith, E., } \\
\text { R. (2016) }\end{array}$ & $\begin{array}{l}\text { The Role of Young Women and Girls project was implemented by non- } \\
\text { governmental organization Search for Common Ground as a component of } \\
\text { Learning for Peace in the Democratic Republic of the Congo and aimed to } \\
\text { consolidate peace by encouraging the participation of young women and } \\
\text { girls in both peacebuilding initiatives and education opportunities. } \\
\text { Equateur's "Learning for Peace" component in the program is dedicated to } \\
\text { addressing four key issues determined by the participation of valuations: } \\
\text { ethnic conflicts, especially between Bantu groups and Minority Batwa }\end{array}$ \\
\hline
\end{tabular}


IJBE (Integrated Journal of Business and Economics) e-ISSN: 2549-3280/p-ISSN: 2549-5933

\begin{tabular}{|c|c|}
\hline Author & Definition \\
\hline & $\begin{array}{l}\text { Group; bad management, especially local government structures; unequal } \\
\text { distribution resources; and poor quality of education very few visitors, } \\
\text { especially girls. }\end{array}$ \\
\hline Davies, K. (2015) & $\begin{array}{l}\text { Education should be seen as integral to humanitarian work itself. This is } \\
\text { part of the concept of 'building back better,' the demand that } \\
\text { reconstruction does not simply reproduce the conditions that contributed to } \\
\text { conflict in the first place. Such conditions may have included unequal } \\
\text { access to education, or normalization of violence in schools. Education has } \\
\text { become caught up in the merging of security and development. Initiatives } \\
\text { in peace will depend on strategic actors' analysis of the causes of conflict; } \\
\text { the 'peace dividend' envisaged is not value free. }\end{array}$ \\
\hline Lenhart, V. (2018) & $\begin{array}{l}\text { Peace education work in crisis and conflict areas actually does help to } \\
\text { make hostile groups more peaceable in their attitudes towards one another. } \\
\text { Compared with persons who have not taken part in such programmes, } \\
\text { participants in so-called peace-building education projects in countries } \\
\text { with armed conflicts often differ distinctly in the extent to which they are } \\
\text { prepared to envisage peaceful conflict settlement. }\end{array}$ \\
\hline $\begin{array}{l}\text { Rubagiza, J., Umutoni, J., } \\
\text { Kaleeba, A. (2016) }\end{array}$ & $\begin{array}{l}\text { Together with education, there are also teachers who are introduced in } \\
\text { different ways around the world, so they are expected to play several roles } \\
\text { in solving various social problems. Teachers are often perceived as factors } \\
\text { in transformational change, including peace representatives. In the context } \\
\text { of conflict-affected societies, teachers play a key role in shaping the } \\
\text { nation, creating identity, peace and reconciliation (Durrani \& Dunne 2010; } \\
\text { Smith et al., 2011). In hopes of peacekeepers, teachers are expected to } \\
\text { disseminate values that support peace, including tolerance, recognition and } \\
\text { respect, and various skills such as critical thinking, negotiation, } \\
\text { compromise and collaboration, as well as interpersonal relationships } \\
\text { among learners (Horner et al. 2015) }\end{array}$ \\
\hline El-Attar, M. (2009) & $\begin{array}{l}\text { In the literature, there is a particular disagreement about the role of } \\
\text { education. While some authors have linked violent and extreme positions } \\
\text { to ignorance and to low market opportunities, others have found that } \\
\text { education is positively correlated with being a member of a terrorist group. } \\
\text { To better understand the role of education I decompose the attitudes } \\
\text { towards peace in two dimensions; attitudes towards reconciliation and } \\
\text { attitude toward concessions. }\end{array}$ \\
\hline
\end{tabular}

\section{Universities Peace Initiative}

As stated Sampere (2016) peace education fights for efforts to tackle violence people's ability to analyze problems act critically and participate in encouraging innocent conflict resolution and, finally, cherish harmonious and cooperative relationships between people. These are all essential features for those who want to influence peace from the most intimate levels to the world. Peace education provides people with the means they can relate to themselves, their immediate environment and the world. In order to achieve this, it acts on cognitive, emotional, moral and political aspects of creating content conveys concepts, teaches procedures and encourages attitude towards peace. 
Peace Studies is an interdisciplinary academic field based on political sciences, sociology, history, anthropology, theology, psychology, philosophy, and other fields:

$>$ to understand the causes of the armed conflict;

$>$ to develop ways to prevent and deal with war, genocide, terrorism, serious human rights abuses; and

$>$ to create peaceful and fair systems and societies.

The School of Humanities at $\boldsymbol{U N E}$. Peace studies deal with inhumane ways of resolving the conflict. Peace workers support individuals, families, communities and the general public in rebuilding conflicts before they erupt into violence. They also cooperate with communities in conflict-affected countries through constructive and participatory ways to help them build peace, reconcile and rebuild societies that are sustainable, environmentally sound and fair. They help communities adapt to change and create peaceful, resilient cultures. Peace studies also address contemporary issues such as globalization, climate change and refugee flows.

University of Toledo. Judith Herb College of Education at Toledo University offers a Bachelor's Interdisciplinary Small Peace Study Program and an online Graduate Diploma Program in Peace Education. These academic programs are complemented by a multitude of research, international and community initiatives supported by the University of the Peace Studies faculty-student network.Peace studies are related to studies, scholarships and actions related to the reduction and elimination of violence and the conditions for prosperity in peace and justice at all levels within the human organization. Adding these perspectives to peacebuilding TU has studied the philosophical, sociological and psychological aspects of the learning and education of the world's citizens, that they will critically understand and transform all forms and ideas that justify and support them.

University Notre Dame. Creating peace and justice at all levels - from ordinary people to universal ones. This Master's Degree in Global Affairs is designed for students who seek to build sustainable peace and justice through policy analysis and political change, government and organizational leadership, conflict analysis and transformation. You will join a global network of over 500 graduate magistrates dealing with violent conflict and peace, human rights and human development, environmental sustainability, and related issues.

University of Michigan. The Conflict and Peace Initiative (CPI) is aimed at deepening the perception of the root causes, dynamics and consequences of conflict and peace. The NCA started operating in 2016. In the autumn, with the support of the International Institute of Enterprise Fund and the University of Michigan. All of our events and projects involve collaborations between the various disciplines and continuous engagement in the anti-violence and anti-discrimination groups. University seeks to support global propaganda organizations by raising awareness of local social justice programs and organizing events of international significance involving those who seek a just and positive peace.

Boston University African Studies Centres. The West African Peace Initiative is a multifaceted WARA / WARC-funded project that aims to foster research and dialogue on peacebuilding and conflict resolution in the region. The project has three main areas: scholarship program, regional 
conferences and journalism institute. The West African Peace Initiative was a project funded by the US Department of State.Peacebuilding in West Africa - regional conferences.

University of Kabianga. University of Kabianga, Peace Initiative Forum (UoKPIF), 2017 September 21 Announced International Peace Day. UoKPIF is a student-led club that maintains peace and harmonious coexistence both inside and outside the university. Students took part in various activities, including:

- Planting trees. Students planted three trees that this year will feature three themes in the theme of the International Peace Day. He was "Together for Peace, Respect, Security and Dignity for All"

- Peace Walk Through the University: Peace travel was held to activate students and the university fraternity for peace and cohesion, especially during the upcoming presidential elections.

\section{Conclusion}

Education is a major peace-building process; it is important to note that it has two aspects. There is evidence that when equally accessible, of good quality, relevant and sensitive to conflict, education can help promote peace and ensure a safe environment. On the other hand, it is characterized by exclusion and inequality; this can strengthen the conflict. It is for this reason that efforts must be made to put in place the necessary strategies and strategies to maximize the positive effects of education on peace. Peacebuilding in education is a more active attitude that peace education is used as a means of building a more stable and peaceful culture, thus preventing violent incidents. Peace education is essential for building a culture that reduces the need to consolidate peace and maintain peace through a comprehensive program that teaches people to interact with others and avoid unnecessary aggression.

\section{References}

1) Ajala, E.M. (2003). The influence of peace education on labour management relations in selected industries in Oyo State, Nigeria. Unpublished doctoral dissertation: Department of Adult Education, University of Ibadan.

2) Benedictine University. (n.d.). Peace Team. Retrieved from http://www.ben.edu/student-life/violenceprevention/

3) El-Bushra, J., Smith, E., R. (2016). Gender, Education and Peacebuilding . A review of selected Learning for Peace case studies.

4) Davies, K. (2015). The Politics of Peace Education in Post-Conflict Countries. CRPD Working Paper No. 32.

5) Djuliman, E. (2017). The Role of Universities in Peacebuilding. http://www.nhc.no/no /vart_arbeid/uttalelser/The+Role+of+Universities+in+Peacebuilding.b7C_wlnU1e.ips

6) Dulnuan, W. (2015). Peace education. https://www.slideshare.net/wdulnuan/peace-education55775719

7) Dupuy, K. (2008). Education for Peace. Building Peace and Transforming Armed Conflict Through Education Systems. International Peace Research Institute, Oslo (PRIO) for Save the Children Norway. Report no. ISBN 82-7481-165-8 
8) El-Attar, M. (2009). Could Education Promote the Israeli-Palestinian Peace Process? IZA DP No. 4447.

9) Gutek, G. L. (2006). American Education in a Global Society. International and Comparative Perspectives. Long Grove, Illinois: Waveland Press, Inc.

10) Guetta, S. (2016). Education for a Culture of Peace and Co-Existence. Studi sulla formazione, 1-2016, p.p. 133-141.

11) Harris, I., M.(2004). Peace education theory. Journal of Peace Education . Volume 1, Issue 1.

12) Harris, I., M.(2002). Peace education: definition, approaches, and future directions. Peace, literature, and art - Vol. I.

13) Harris, I., M. , Synott, J. (2002). Peace education for a new century. Social Alternatives. 2002; 21(1): 3-6.

14) International Peace Studies. (n.d.). Retrieved from http://keough.nd.edu/master-of-globalaffairs/international-peace-studies/

15) Kester, K. (2009). Education for Peace: Content, Form, and Structure: Mobilizing Youth for Civic Engagement. Conference Papers. http://www.review.upeace.org/index.cfm?opcion=0\& ejemplar $=19 \&$ entrada $=101$

16) Leyaket (2016). The Importance of Peace Education for the Youth in Singapore. http://icrs.ugm.ac.id/news/186/the-importance-of-peace-education-for-the-youth-in-singapore.html

17) Lirola, M., M. (2016). A proposal to combine cooperative learning and peace education in a foreign language subject. Journal in Global Research in Education and Social Sciences, 5(2), p.p.102-111.

18) Lirola, M., M. (2007). El nuevo papel del profesor universitario en el proceso de convergencia europea y su relación con la interacción, la tutoría y el aprendizaje autónomo." Porta Linguarum. Revista Internacional de Didáctica de las Lenguas Extranjeras. 7:, p.p.. 31-43.

19) Mahmood, A., Ashraf, I. (2014). Peace education: conceptual awareness of teachers at elementary. International Journal of Educational Science and Research (IJESR), Vol. 4, Issue 18.

20) McGuire, D. (2018). What is Peace Education? - Objectives \& Importance. https://study.com/academy/lesson/what-is-peace-education-objectives-importance.html

21) MGIEP/UNESCO (2014). Education for peace and sustainable development. Concepts, clarity and cohesion a set of papers commissioned by MGIEP.

22) Mirra, C. (2008). United States foreign policy and the prospects for peace education. Jefferson, NC, and London: McFarland \& Company, Inc.

23) Naik, A., K., Behera, S.K. (2013). Peace education in India: a proposal. International Journal on New Trends in Education and Their Implications, Volume 4, Issue 2, p.p.89-97.

24) Nair, G. (2018). Peace education and conflict resolution in school. Health Administrator Vol: XVII, Number 1: p.p. 38-42.

25) Nakamura, K. (2018). International Education for Peace in Higher Education. Promoting Cultures of Peace in Japan. http://www.konan-u.ac.jp/hp/koji/pdf/Peace\%20Education\%20.pdf

26) Nedelea, A., M., Nedelea, M., O. (2015). Peace marketing. Ecoforum. Volume 4, Issue 2 (7).

27) Novakova, P. (2010). The Discourse of Unity: Constructing Peace through Education in the Chittagong Hill Tracts. Master Thesis. Radboud University Nijmegen, The Netherlands http://theses.ubn.ru.nl/bitstream/handle/123456789/3007/2010\%20Novakova.pdf?sequence=1

28) Page, James S. (2008) Peace Education: Exploring Ethical and Philosophical Foundations. Charlotte: Information Age Publishing. p. 189. 
29) Peace Education - The Development of Peace Education and Its Basic Principles - Conflict, Individual, World, and Society - StateUniversity.com http://education.stateuniversity.com/pages /2314/Peace-Education.html\#ixzz59EgGgiTl

30) Peace and Human Security in Asia. (n.d.). Retrieved from http://peace-hs.osipp.osaka-u.ac.jp/

31) Program on Justice and Peace. (n.d.). Retrieved from https://justiceandpeace.georgetown.edu/

32) Ran, I. (2015). Role of Education in Inculcation of Education For Peace. Issues and Ideas in Education Vol. 3, No. 2, pp. 103-116.

33) Reardon, B. (1997). Human Rights as Education for the Twenty-First Century. Philadelphia: University of Pennsylvania Press, p.p. 255-261.

34) Rubagiza, J., Umutoni, J., Kaleeba' A. (2016). Teachers as agents of change: promoting peacebuilding and social cohesion in schools in Rwanda. Educ. as change vol.20 n.3 Pretoria

35) Rubina, B. (2010). Libraries and Education for Peace in Pakistan. Library Philosophy and Practice (ejournal). 467. http://digitalcommons.unl.edu/libphilprac/467

36) Sampere, M. C. (2016). Peace and Coexistence Education in School Settings: A Teacher Training Perspective.

37) Saroja, R.T. (2016). Peace education. International Journal of Advanced Research and Innovative Ideas in Education. Vol-2, Issue-1, p.p. 694-699.

38) Sharma, V., Jain, S. (2012). Peace education and human rights in twenty-first century: a review. International Journal of Social Science \& Interdisciplinary Research Vol.1 Issue 12,p.p.197-203

39) Spruyt,B., Elchardus, M., Roggemans, L., Van Droogenbroeck, F. (2014). Can peace be taught? Researching the effectiveness of peace education.

40) South House Exchange Ottawa, Canada (2001). Education for Peace, Human Rights, Democracy, International Understanding and Tolerance.

41) The role of education in promoting peace. (n.d.). Retrieved from https://www.globalpartnership.org/blog/role-education-promoting-peace

42) United Nations Educational, Scientific and Cultural Organisation (2005). Peace Education Framework for Teacher Education.

43) United Nations Children's Fund (2011). The Role of Education in Peacebuilding: A synthesis report of findings from Lebanon, Nepal and Sierra Leone. New York.

44) UNESCO (2014). Global Citizenship Education - Preparing Learners for the Challenges of the Twenty-first Century, 2014, http:// unesdoc.unesco.org/images/0022/002277/227729E.pdf

45) UNICEF (2011). The role of education in peacebuilding. Literature review.

46) University of Kabianga. (n.d.). Retrieved from http://kabianga.ac.ke/main/

47) University of Notre Dame. (n.d.). What is Peace Studies? // Kroc Institute for International Peace Studies // University of Notre Dame. Retrieved from https://kroc.nd.edu/about-us/what-is-peacestudies 